\title{
Rapid Indicators in Detecting Variation of Fly Ash for Making HVFA Concrete
}

\author{
Antoni $^{1,2, a}$, Rianto Gunawan ${ }^{3, b}$ and Djwantoro Hardjito ${ }^{1,2, c}$ \\ ${ }^{1}$ Department of Civil Engineering, Petra Christian University, Indonesia \\ ${ }^{2}$ Center of Excellence Geopolymer \& Green Technology (CEGeoGTech), School of Materials \\ Engineering, Universiti Malaysia Perlis, Malaysia \\ ${ }^{3}$ Postgraduate Program in Civil Engineering, Petra Christian University, Indonesia \\ aantoni@petra.ac.id, ${ }^{b}$ rian.go88@gmail.com, ${ }^{\text {c}}$ djwantoro.h@petra.ac.id
}

Keywords: Fly ash, pH, HVFA, Superplasticizer demand, Temperature, Setting time, Strength.

\begin{abstract}
The use of fly ash as an alternative material for cement substitute in concrete mix already a common practice nowadays. However, as a waste material, fly ash varies in quality and condition, as shown by variation of its fineness, specific gravity, Loss on Ignition (LOI) and also on its chemical composition. By measuring the acidity $(\mathrm{pH})$ of the fly ash in water solution, percentage of mass retained on $45 \mu \mathrm{m}$ sieve, and superplasticizer demand of the fly ash, we can develop a quick estimation of the quality of fly ash. This study aims to investigate a quick method to estimate the quality of fly ash by measuring the physical and chemical pointers, as indicator for its properties and the effect on the setting time and compressive strength of mortar. Fly ash content was varied from $0-70 \%$ of the total mass of cementitious materials to make HVFA mortar. Fly ashes were obtained from four power plants in Indonesia. Tests conducted were material characterization, setting time, temperature rise, and compressive strength of mortar at different ages. Different fly ash quality can be shown by the fast pointers; namely $\mathrm{pH}$, superplasticizer demand and $\%$ retained on $45 \mu \mathrm{m}$ sieve. Setting time and strength development were affected by the different properties of fly ash.
\end{abstract}

\section{Introduction}

Fly ash is generally obtained as a waste from coal fired power plant. The quality or content of fly ash varies due to the different supply of coal and different combustion methods and so on. The variation is dependent on the source of the coal, combusting equipment, carbon content, particle fineness $[1,2]$. Variations of fly ash can be easily detected by measuring the acidity $(\mathrm{pH})$ of fly ash in distilled water. Several reports mentioned that the levels of $\mathrm{pH}$ and temperature can affect the reactivity of fly ash and strength of concrete containing fly ash [3-5]. It requires a $\mathrm{pH}$ value of at least 13 to start the pozzolanic reaction of fly ash in the mixture of Portland cement. Alkalinity, as the opposite of acidity, of fly ash is the main variable that can control the solubility and movement of water contained in the fly ash. The variation of fly ash needs to be characterized in early stage. High quality fly ash can be readily used, while low quality fly ash requires beneficiation process [6].

To minimize the use cement, this research focuses on the use of high volume fly ash (HVFA) mixture. HVFA is the term used when the use of fly ash in concrete mixtures exceed $50 \%$ of the total cementitious material [7]. The focus is on rapid detection of quality of fly ash by measuring its $\mathrm{pH}$ levels in distilled water solution, percentage of mass retained in $45 \mu \mathrm{m}$ sieve and superplasticizer demand to obtain a workable mixture. Testing was conducted on the properties of fresh and hardened concrete, i.e. mortar flow, setting time, temperature rise and concrete compressive strength at 3, 7, 14, 28 and 56 days. It was found that the method can serve as a guide for the determination of fly ash quality as material for making HVFA mortar or concrete. With that, the proportion of the mixture can be altered easily, adjusting to the quality of fly ash used. 


\section{Experimental Program}

Material Preparation. Fly ash samples were taken from several power plants in Java, Indonesia. Figure 1 shows the four different fly ash samples, i.e. from Paiton Power Plant unit 5-6, Probolinggo (YT), from Tanjung Jati Power Plant, Jepara (TJ), from Paiton Power Plant unit 1-2, Probolinggo (PJ) and from Rembang Power Plant (RB). Table 1 shows the $\mathrm{pH}$ value, the chemical compound and physical properties of the fly ash samples. Distilled water was used troughout the study. In the determination of $\mathrm{pH}$ value, $20 \mathrm{gr}$ fly ash was mixed with $80 \mathrm{gr}$ distilled water; $\mathrm{pH}$ was measured after 2 hours [8]. Specific surface area (SSA) was analyzed by conducting particle size analysis. Percentage of mass retained on $45 \mu \mathrm{m}$ sieve was also measured. Portland Pozzolan cement (PPC) produced by Semen Gresik was used as cementing material, in combination with fly ash. Fine aggregate used was of river sand from Lumajang, with specific gravity of 2.72 and fineness modulus of 2.13 .
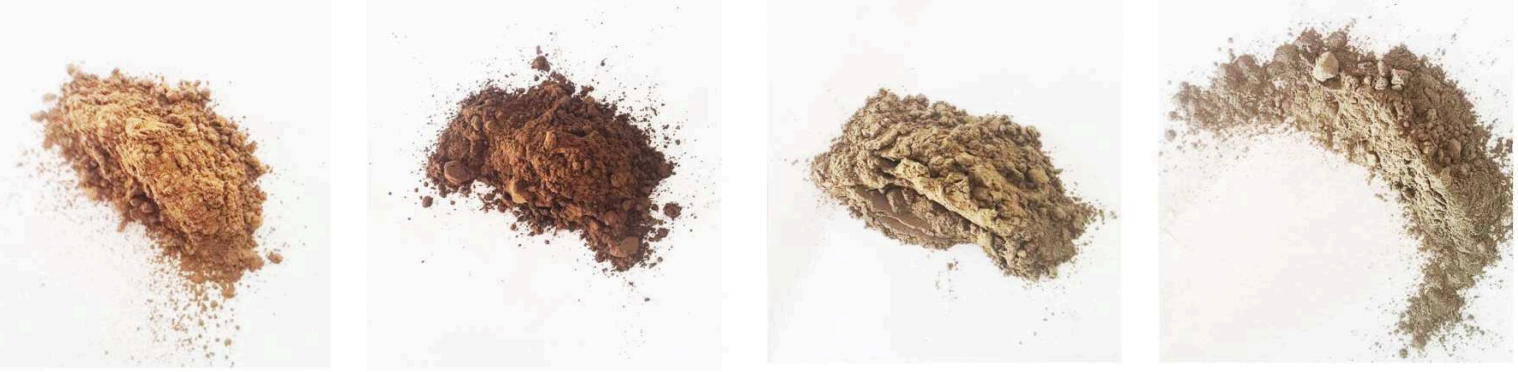

Figure 1. Sample fly ash YT, TJ, PJ dan RB (from left to right)

Table 1. Chemical compound and properties of fly ash

\begin{tabular}{ccccc}
\hline Component & $\begin{array}{c}\text { Fly ash YT } \\
\text { pH 11.6 } \\
\text { Type C }\end{array}$ & $\begin{array}{c}\text { Fly ash TJ } \\
\text { pH 10.6 } \\
\text { Type F }\end{array}$ & $\begin{array}{c}\text { Fly ash PJ } \\
\text { pH 10.3 } \\
\text { Type F }\end{array}$ & $\begin{array}{c}\text { Fly ash RB } \\
\text { pH 9.6 } \\
\text { Type F }\end{array}$ \\
\hline $\mathrm{CaO}$ & 16.33 & 9.15 & 5.49 & 4.03 \\
\hline $\mathrm{SiO}_{2}$ & 37.58 & 38.24 & 51.03 & 50.14 \\
\hline $\mathrm{Al}_{2} \mathrm{O}_{3}$ & 17.35 & 15.28 & 25.13 & 29.08 \\
\hline $\mathrm{Fe}_{2} \mathrm{O}_{3}$ & 14.17 & 24.28 & 9.66 & 9.66 \\
\hline $\mathrm{K}_{2} \mathrm{O}$ & 1.33 & 0.78 & 1.58 & 1.53 \\
\hline $\mathrm{MgO}_{\mathrm{SO}_{3} \mathrm{O}}$ & 6.68 & 5.19 & 3.25 & 1.11 \\
\hline $\mathrm{P}_{2} \mathrm{O}_{5}$ & 1.58 & 0.61 & 0.51 & 0.77 \\
\hline $\mathrm{TiO}_{2}$ & 0.26 & 0.09 & 0.23 & 0.67 \\
\hline $\mathrm{Cr}_{2} \mathrm{O}_{3}$ & 0.69 & 0.81 & 1.16 & 1.51 \\
\hline $\mathrm{Na}_{2} \mathrm{O}$ & 0.02 & 0.02 & 0.02 & 0.02 \\
\hline $\mathrm{LOI}_{\text {Specific Gravity }}$ & 2.96 & 0.80 & 1.51 & 0.79 \\
\hline \% retain in $45 \mu \mathrm{m} \mathrm{sieve}$ & 0.40 & 3.90 & 1.44 & 0.63 \\
\hline & 2.83 & 2.92 & 2.49 & 2.25 \\
\hline Specific Surface area $\left[\mathrm{gr} / \mathrm{cm}^{3}\right]$ & 2629 & 2078 & 1370 & 1169 \\
\hline & 10.5 & 16 & 22.6 & 27.0 \\
\hline
\end{tabular}

Table 2. Superplasticizer demand and flow diameter of sample mixture

\begin{tabular}{ccccccccc}
\hline & \multicolumn{2}{c}{ YT } & \multicolumn{2}{c}{ TJ } & \multicolumn{3}{c}{ PJ } & \multicolumn{2}{c}{ RB } \\
\hline Mixture & $\begin{array}{c}\text { Sp } \\
\text { required } \\
{[\% \mathrm{CM}]}\end{array}$ & $\begin{array}{c}\text { Flow } \\
\text { diameter } \\
{[\mathrm{cm}]}\end{array}$ & $\begin{array}{c}\text { Sp } \\
\text { required } \\
{[\% \mathrm{CM}]}\end{array}$ & $\begin{array}{c}\text { Flow } \\
\text { diameter } \\
{[\mathrm{cm}]}\end{array}$ & $\begin{array}{c}\text { Sp } \\
\text { required } \\
{[\% \mathrm{CM}]}\end{array}$ & $\begin{array}{c}\text { Flow } \\
\text { diameter } \\
{[\mathrm{cm}]}\end{array}$ & $\begin{array}{c}\text { Sp } \\
\text { required } \\
{[\% \mathrm{CM}]}\end{array}$ & $\begin{array}{c}\text { Flow } \\
\text { diameter } \\
{[\mathrm{cm}]}\end{array}$ \\
\hline $\mathbf{0 \%}$ & 0.20 & 13.3 & - & - & - & - & - & - \\
\hline $\mathbf{1 0} \%$ & 0.18 & 13.7 & 0.18 & 13.7 & 0.09 & 13.0 & 0.18 & 13.0 \\
\hline $\mathbf{2 0} \%$ & 0 & 13.9 & 0.16 & 13.0 & 0.16 & 13.0 & 0.24 & 14.2 \\
\hline $\mathbf{3 0 \%}$ & 0 & 14.5 & 0 & 13.7 & 0.14 & 13.5 & 0.21 & 14.8 \\
\hline $\mathbf{4 0 \%}$ & 0 & 15.8 & 0 & 15.5 & 0.06 & 13.7 & 0.18 & 15.2 \\
\hline $\mathbf{5 0} \%$ & 0 & 16.7 & 0 & 16.5 & 0 & 13.7 & 0.15 & 14.5 \\
\hline $\mathbf{6 0} \%$ & 0 & 18.2 & 0 & 17.0 & 0 & 13.9 & 0.16 & 14.7 \\
\hline $\mathbf{7 0} \%$ & 0 & 19.3 & 0 & 18.5 & 0 & 14.5 & 0.15 & 15.0 \\
\hline
\end{tabular}

Mixture Composition. The mixtures of HVFA mortar were prepared with the amount of fly ash content varies from 0 to $70 \%$ of the total cementitious material (CM), with $10 \%$ interval. The total cementitious material and sand ratio was set constant at 0.5 , by mass. Cementitious material, i.e. a 
combination of PPC and fly ash, was mixed with distilled water (W), with W/CM ratio of 0.35. Polycarboxylate superplasticizer was added, if required, to produce a workable mortar mixture with target flow diameter of minimum $13 \mathrm{~cm}$ in flow table test. The superplasticizer demand is shown in Table 2 . Most mixtures only need $0-0.16 \%$ SP for low fly ash content mixtures to achieve the target workability. The higher the fly ash content, the lower the SP demand. The only exception was fly ash $\mathrm{RB}$, as it required higher superplasticizer addition, and it continued even at high fly ash content. Each fresh mixture was tested for a Vicat setting time, temperature rise, and casted in $5 \times 5 \times 5 \mathrm{~cm}^{3}$ moulds for compressive strength testing. The specimens were immersed in tap water bath for curing until one day before testing. Compressive strength was tested at 3, 7, 14, 28 and 56 days of age.

\section{Results and Discussion}

Indicators of Fly Ash Characteristics. Fly ash chemical compound measured by XRD provides the best description of its characteristics. However, this test is expensive and the result may not be readily available immediately. Measuring $\mathrm{pH}$ level and conducting sieve analysis on fly ash, aside from Foam Index Test, can be fast methods to estimate the quality of fly ash. Figure 2(a) shows relationship of pH values and $\mathrm{CaO}$ content of the fly ash samples. It shows nearly linear relationship, whereby the higher $\mathrm{CaO}$ content, the higher the $\mathrm{pH}$ value of fly ash. $\mathrm{pH}$ value can immediately give indication of the calcium content of the fly ash. The same is for the relationship between specific surface area (SSA) and percentage of mass retained on sieve $45 \mu \mathrm{m}$, as shown in Figure 2(b). However, more data are needed to produce better correlation curves.
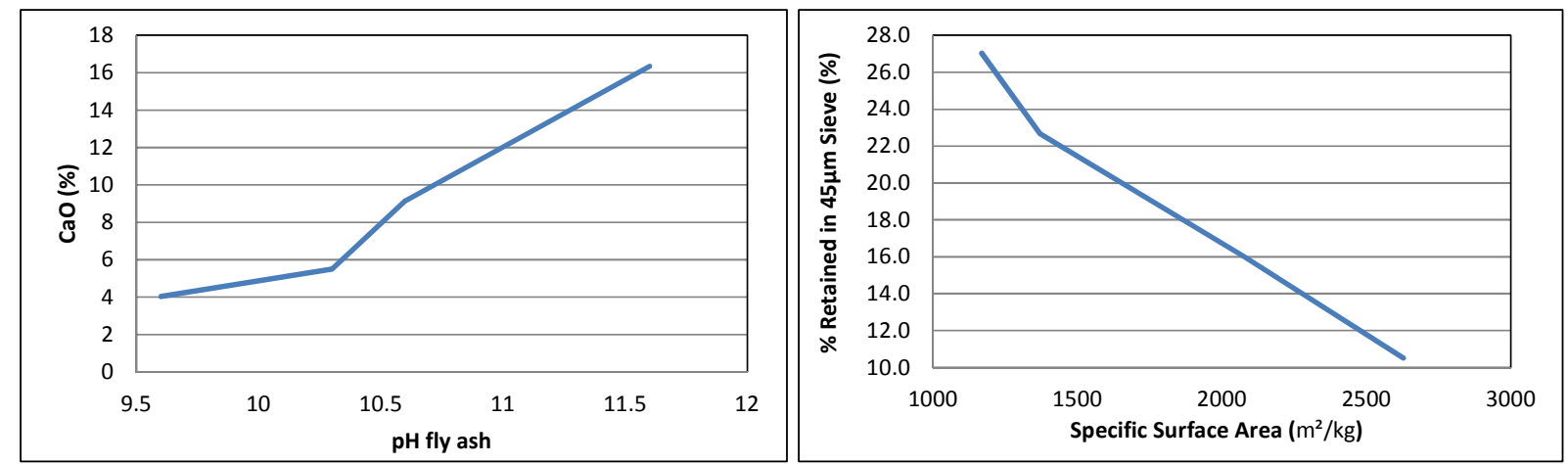

Figure 2. Correlation of (a) $\mathrm{pH}$ and $\mathrm{CaO}$ content of fly ash and

(b) Specific Surface Area and \% retained on $45 \mu \mathrm{m}$ sieve.

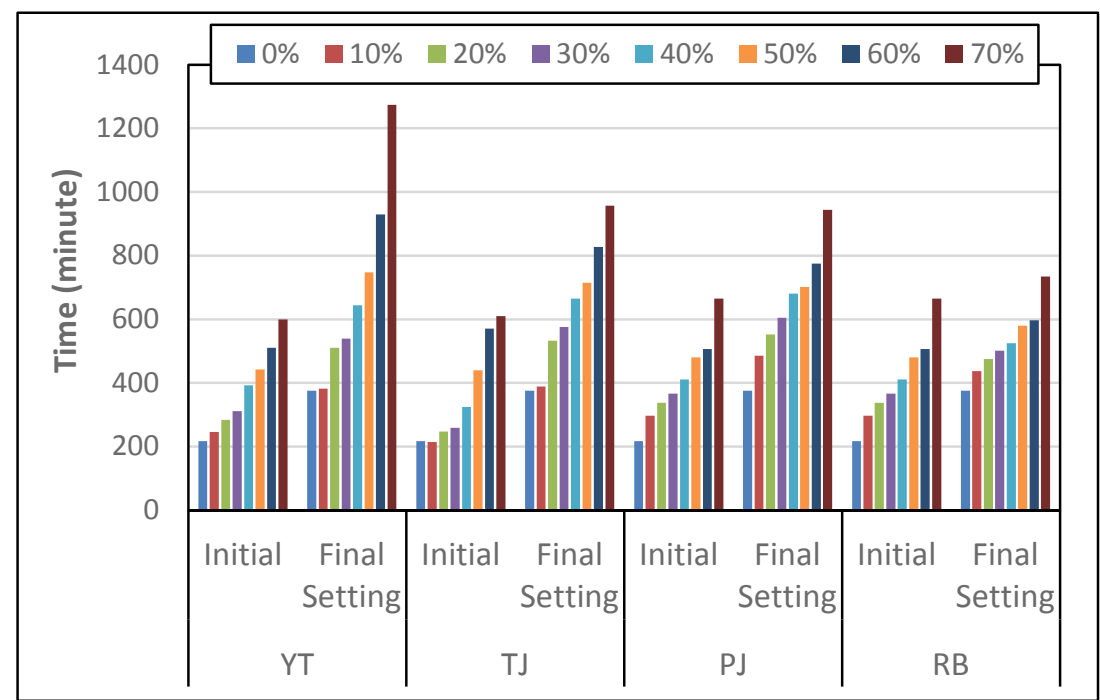

Figure 3. Initial and final setting time paste with various fly ash content

Setting Time. Setting time of the paste was measured by Vicat needle. The results are shown in Figure 3. As already well-known, setting time of paste is generally increased with the increase of fly 
ash content in the mixture. However, the increase of setting time seems to have an inverse correlation with the $\mathrm{pH}$ level of the fly ash. Most of the mixtures containing fly ash with higher $\mathrm{pH}$ value has shorter initial setting, and - on the other hand - longer final setting time. Using $50 \%$ replacement of cement with fly ash delays the setting time twice of the mixture without fly ash.

Temperature Rise. The temperature rise was measured on $400 \mathrm{gr}$ of paste sample contained in a polystyrene box. The temperature rise were measured for 72 hours. Figure 4(a) shows temperature evolution of the mixture with different fly ash content for fly ash YT. Increase the fly ash content lowers the peak of the temperature evolution and prolong the time when it happens (i.e. peak time). Comparison of the peak of the temperature and the peak time for the four types of fly ash used is shown in Figure 4(b). Different type of fly ash shows different peak time; however the peak temperature is similar one to the other, meaning that the heat of hydration is mostly generated by the Portland cement. Different duration to reach the peak temperature needs to be considered if high volume of fly ash is to be used. This could be influenced by the chemical composition of fly ash.
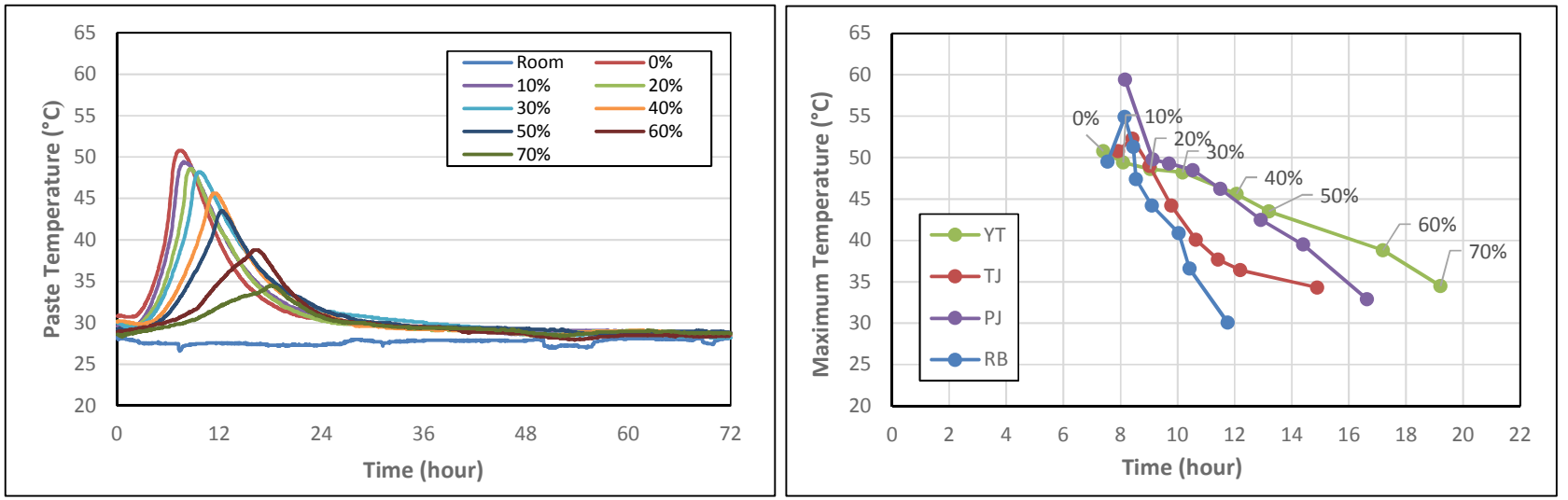

Figure 4.(a) Temperature of evolution of paste mixtures with different fly ash YT content, and (b) Peak temperature and peak time for different fly ash.

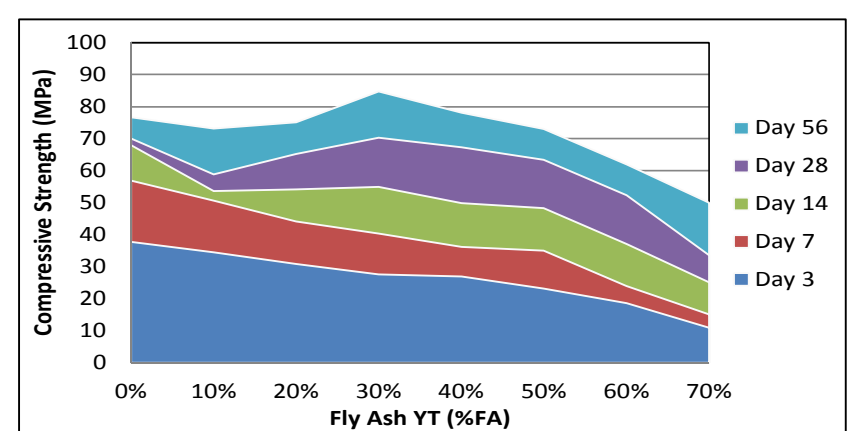

(a)

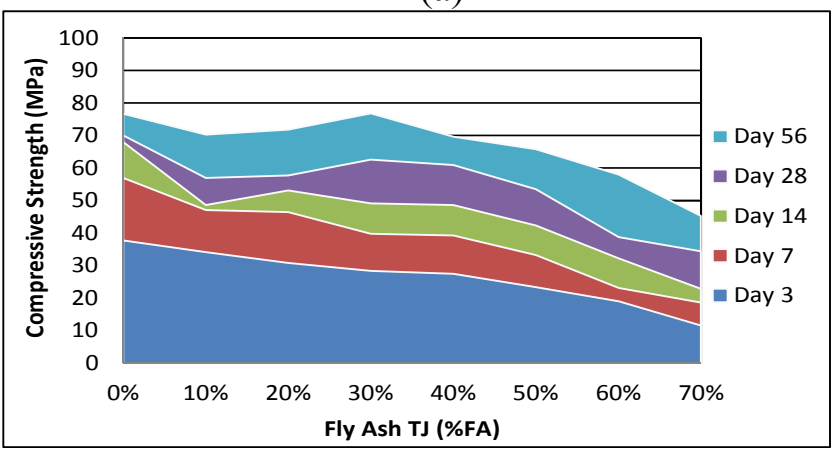

(c)

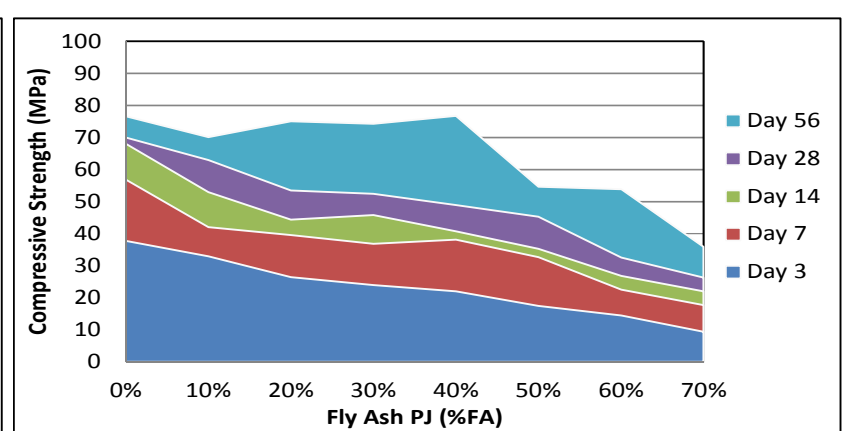

(b)

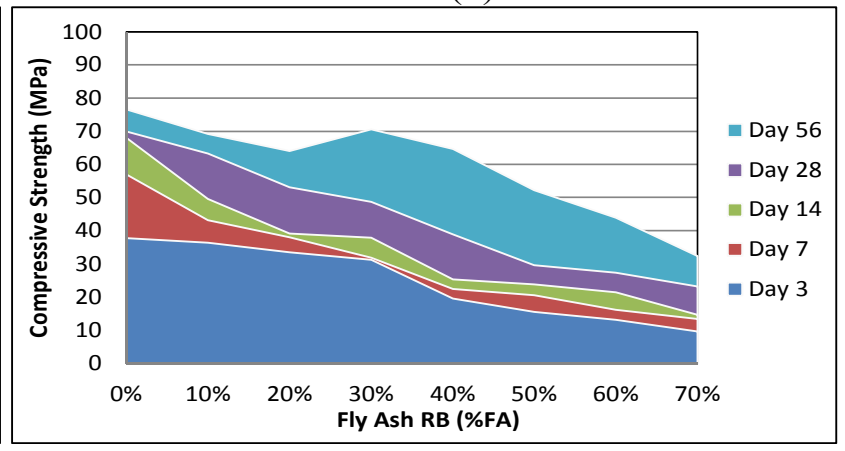

(d)

Figure 5. Compressive strength development of paste with different fly ash content for (a) Fly ash YT, (b) Fly ash PJ, (c) Fly ash TJ and (d) Fly ash RB.

Compressive Strength. Figure 5 shows the compressive strength development of mortar containing fly ash from different sources. It is shown that the compressive strength tends to decrease 
with the increase of fly ash content. However, there is significant increase on the compressive strength of mortar from 28 days to 56 days, especially when the fly ash content ranges from 20 to $40 \%$, for all types of fly ash. Fly ash YT shows even high increase of strength from 14 days to 28 days of age, indicating that the pozzolanic reaction could take place at earlier concrete age. This can be attributed to the large specific surface area of the fly ash, accelerating the reaction process. Similar strength to the one without any fly ash content was achieved by mortar containing 30-40\% fly ash, from all types, at 56 days concrete age, showing that all four types of fly ash used in this study have very high potential to be used as cement replacement material in concrete mixture.

\section{Conclusions}

Variation of fly ash obtained from different sources can cause variation on the properties of concrete mixture. The variation can be attributed to its chemical composition or its physical properties. From this research, several outcomes were obtained, i.e.:

Measuring the $\mathrm{pH}$, particle retained on $45 \mu \mathrm{m}$ sieve and superplasticizer demand can be used as rapid indicators of fly ash chemical and physical properties, in terms of calcium content, fineness and particle shape; that affect different fresh and hardened concrete properties.

The use of fly ash in concrete mortar or concrete mixture increases its setting time, but the increment also depend on the chemical properties of the fly ash. High calcium fly ash tends to cause relatively shorter initial setting time and longer final setting time.

Temperature rise due to concrete hydration decreasea with the increase of fly ash content, as it is mainly determined by the amount of cement content.

Compressive strength of concrete or mortar containing 30-40\% fly ash is comparable to the control concrete with no fly ash content at the age of 56 days. This shows the high potential of fly ash to be used in concrete mixture.

\section{Acknowledgements}

The authors gratefully acknowledge The Directorate General for Higher Education, Ministry of Education and Culture, Indonesia, who provided the research grant through the 'Hibah Kompetensi" scheme in 2014 and 2015.

\section{References}

[1] NTPC Ash Utilization Division (2007). Fly ash for cement concrete: Resources for high strength and durability of structures at lower cost.

[2] Energy Weekly News (2012). Treatment of fly ash for use in concrete.

[3] Fraay, A., \& Bijen, J. M. (1990). Cement stabilized fly ash base courses. Cement \& Concrete Composites, Vol (12), 279-291.

[4] Brouwers, H. J. B., \& Eijk, R. J. Van. (2003). Chemical reaction of fly ash. The Cement and Concrete Institute of South Africa, Vol (5), 791 - 800.

[5] Bouzoubaa, N., Fournier, B., Malhotra, M.V., \& Golden, D.M. (2001). Mechanical properties and durability of concrete made with HVFA blended cement produced in a cement plant. Electric Power Research Institute, 1-18.

[6] Antoni, and Satrya, V and Hardjito, D.: Simple Mechanical Beneficiation Method of Coarse Fly Ash with High LOI for Making HVFA Mortar. Civil Engineering Dimension, (2015) 17 (1). pp. 38-43. ISSN 1979-570X

[7] Crouch, L. K., Hewitt, R., \& Byard, B. (2007). High volume fly ash concrete. World of Coal Ash, $1-14$.

[8] ASTM D5239-12. Standard Practice for Characterizing Fly Ash for Use in Soil Stabilization 